Portland State University

PDXScholar

Institute of Portland Metropolitan Studies

Publications

Institute of Portland Metropolitan Studies

January 2000

Portland and smart growth: What you can learn from the Portland experience

Ethan Seltzer

Portland State University

Follow this and additional works at: https://pdxscholar.library.pdx.edu/metropolitianstudies

Part of the Urban Studies and Planning Commons

Let us know how access to this document benefits you.

Citation Details

Seltzer, E. (2000) Portland and Smart Growth: What you can learn from the Portland Experience - draft. (New York University).

This Article is brought to you for free and open access. It has been accepted for inclusion in Institute of Portland Metropolitan Studies Publications by an authorized administrator of PDXScholar. Please contact us if we can make this document more accessible: pdxscholar@pdx.edu. 


\section{PORTLAND AND SMART GROWTH: WHAT CAN YOU LEARN FROM THE PORTLAND EXPERIENCE}

\section{Prepared from Remarks Delivered to the Conference on Cities in North America New York University, New York City June, 1995}

Draft - February 16, 2000

As the nation turns its attention to growth management and smart growth, the magnifying glass is being focused on Oregon and the Portland-Vancouver metropolitan area. The Oregon statewide land use planning program is a 26-year work in progress, longer if you include earlier less successful precursors. It is known for the use of urban growth boundaries, preservation of farm and forest land, and the rigorous use of comprehensive planning shaped from outside the local community by statewide planning goals.

The Portland region is known for its regional government, Metro, its sustained effort to develop a truly multimodal regional transportation system, including the use of light rail, and its collaborative approach to regional growth management that exacts mutual accountability from all jurisdictions within Metro's jurisdiction, south of the Columbia River. Long a source of interest and sometimes inspiration for planners and regionalists, the Portland experience is now drawing the attention of commentators ranging from the Congress of New Urbanism to the Reason Public Policy Institute to the Natural Resources Defense Council. In addition to the national attention, the history and current initiatives in Portland also draw attention from an international audience. The author has personally spoken to groups from the Netherlands, Budapest, Prague, several Japanese metropolitan areas, and Copenhagen within the last six months.

Sometimes, particularly in this run-up to the next Presidential election, it seems like everyone has an attitude on smart growth, and Portland's experience, or at least they're trying to. The conversation at the national level has become progressively more shrill, starting with Al Gore's embrace of smart growth on the campaign trail, and George Will's broadside in the Wall Street Journal.

The debate seems to be boiling down to a familiar one for most planners: the legitimacy of employing collective action to address the failure of the status quo to produce livable, resilient settlement patterns in our metropolitan regions. Regardless of how you feel about either the suburbs or the cities, grassroots citizen initiatives to enact growth boundaries, growth controls, and growth management efforts stand as testimony to the fact that as the nation's population becomes increasingly metropolitan, the nation's metropolitan areas aren't working very well. 
To be sure, some of the forces at work are not all that laudable. Citizen desires to avoid contact with people different than they are, in terms of race, ethnicity, and socioeconomic standing, still exerts a strong push and pull on the desire to control growth. However, in addition to these longstanding dynamics in American society are relatively new concerns regarding environmental degradation, sense of place, community capacity, and urban design. Rather than the dawn of an era where place would become interchangeable, we are in fact beginning to understand that place has become on one hand a matter of choice, and on the other a signature element in defining local, even household relationships to the emerging global knowledge economy.

As more and more communities seek new approaches to both defining the challenges of late 20th-century urban development and addressing them, attention is turning with a vengeance to smart growth and regional growth management. As this discussion leaves the dining room for the school auditorium, enters city hall and even stalks the halls of the Capitol in Washington, D.C., the search is on for "best practices", and in our experience, that search is turning up the heat here in Portland on what our experience has been and what it might mean for us and for others.

10 Lessons...

If you are thinking of visiting us, or as you consume the analysis of pundits foreign and domestic, keep in mind that every community must make its own successes. There is no software available for making one place just like another, because no place is really like any other. What we've done has emerged from who and what we are. The urban growth boundary works for us, but it is certainly not the only planning tool for limiting sprawl and preserving resource land.

If you visit or study us, look carefully not just at how we've done things, but why we've done them. That for us is where the true test lies, and for you, too. The point is not that you ought to employ the tools that we've used, but that you ought to select ones that best fit the problem you're trying to solve and the kind of place that you come from. Nonetheless, take heart. Much can be done, and our experience offers up ten lessons worth discussing in your home town:

1) This is not an Experiment - Often the Portland experience is described as an experiment. It's not. We are doing what we are doing because it's important to us. This region did not set out to become a national model. Instead, it sought to serve the values that have consistently characterized this community: a real desire to make up our own minds and solve our own problems, and significant concern for the environment. This is an intentional place, and what we've done is the result of an ingrained desire to serve it well. As former Governor Tom McCall, "father" of the Oregon planning program, once said, "Heroes are not giant statues framed against a red sky. They are people who say: This is my community and it's my responsibility to make it better". This is also an apt description of what has kept us going. 
There are no controls in this business. You can't go back and "run the experiment" again with a different set of parameters. Consequently, this is not an experiment just as what is happening in your community is no experiment either. There is no such thing as doing nothing. Every move you make and don't make is part of what you will become. Places can choose a future, but they cannot choose not to choose. You might as well articulate your choice accurately, and actively make it your choice, since you'll be living with the consequences anyway.

2) Planning Matters - Through planning you can change the patterns that rule your landscape, and you can make things happen. As Lew Hopkins, Garret Knaap, and their colleagues have shown, plans matter. The experience that we've had in downtown Portland demonstrates that planning matters. In the early 1970's, a revolution of sorts was brewing in Portland. Urban renewal efforts of the late 1950's and 1960's had destroyed city neighborhoods in the name of trying to save them. Planning in the mid-1960's called for even more highways, again as a means for saving neighborhoods.

As one activist of the time has said, after protesting the Viet Nam war for the better part of a decade, they read Jane Jacobs' The Death and Life of Great American Cities and decided to save the city. A new generation of City Commissioners got elected at the end of the 1960's, among them a charismatic young lawyer by the name of Neil Goldschmidt, destined to become mayor a few years later. A proposal to build a 10-story parking structure at the $100 \%$ corner in downtown Portland galvanized a protest movement in opposition to the planning and plans of the time.

As a means to provide certainty, downtown landowners and business interests turned to planning and the incorporation of the rising tide of dissent into the direction for downtown. The result was the 1972 Downtown Plan, widely hailed as the blueprint for the ongoing turnaround for downtown Portland at the time that other downtowns were losing their grip. Some 25 years later, the success of the downtown plan was recognized through the development of a walking tour of its highlights, a celebratory dinner attended by over 700 , and a day-long event to set the course for the next 25 years that drew the participation of 200 over the months leading to the event and 450 on the day that it took place.

Downtown Portland remains a work in progress, a celebrated work in progress. Planning crystallized the vision, made roles and responsibilities clear, and provided common ground that has sustained nearly three decades of investment and public policy. The old dictum "make what you want easy and what you don't want hard" still stands as the primary aspiration.

3) Participation Matters - Citizen involvement in planning is not a particularly dramatic notion these days. There are several reasons for seeking widespread participation in local planning efforts. Participation offers cover and legitimacy to decisionmakers and planners. However, it also contributes two essential elements that contribute to successful plans. First, widespread 
participation increases the range of ideas at the table. More eyes on the problem means more insight into its real nature and possible solutions (JPL article). Second, involving a wide range of folks makes ownership of the results, the plan, widespread, particularly during the years and decades that it takes to act on plans.

Planning is an important part of the kind of community building needed to sustain values and visions over the long haul. Participation made Metro's Region 2040 planning process possible. In the late 1980's Metro had no growth management program. It managed the region's urban growth boundary, but in a very limited way with one half-time planner. As the metropolitan area began to emerge from a prolonged recession during the 1980 's, Metro was called on the review the urban growth boundary as part of the "periodic review" process in the Oregon statewide land use planning program. As part of that review, Metro proposed to develop a set of Regional Urban Growth Goals and Objectives, a long-deferred responsibility identified in its initial enabling legislation.

In the Portland way, a "Noah's Ark" of a committee was constituted to guide the process with membership consisting of elected officials from throughout the region, environmentalists, home builders, business interests, and citizens. After a year of developing goals for urban form in ten categories, the committee recognized that something needed to be done, and that Metro had the power to make it happen. The next year was spent developing the outlines of the regional planning partnership in place today, a component of the document that spelled out how Metro would do regional planning, and what the roles and responsibilities would be for all involved and effected.

At the end of this two-year process, it was suburban elected officials that observed that although they and Metro had developed a great description of the pieces of a well-functioning region, there was no vision, no overall description of where we were heading. It was the participants themselves that called for the creation of what is now known as the Region 2040 Growth Concept, not Metro. Metro's signature growth management planning effort would have never happened without the participation of a wide range of interests.

4) Leadership Matters - Unquestionably, Oregon and the Portland region have benefited from terrific leaders that have made critical contributions at different points in time. Former Governor Tom McCall and key legislative leaders from both parties made the Oregon statewide land use planning program a reality. Former Governor and Mayor of Portland Neil Goldschmidt has been widely credited with leading the revival of Portland's downtown, neighborhoods, and civic culture. Today we continue to benefit from key leaders in critical positions, people able to accurately name the problem, see the connections between interests, and inspire us to be better than we are. 
However, the role for leadership has changed substantially in the last 25 years. Leaders no longer control information like they used to. We have neighborhood activists running ArcView on their home computers.

Information is now everywhere. Furthermore, in this community interests are divided finely enough that we no longer find ourselves with one "lead" issue that pulls folks together. Consequently, the future for us will be in coalitions, and the leaders of the future will be those able to create the partnerships and collaborations needed to advance overall community values.

5) Good Things Take Time - Our region is a work in progress. It's not done and it never will be. Things weren't always like they are today. Lewis Mumford visited our region in the 1930's at the behest of a group of leaders investigating the ways that electrification could be integrated into the Pacific Northwest. Mumford had this to say about Portland and Seattle:

...neither Portland nor Seattle show, from the standpoint of planning, more than metropolitan ambitions that have over-reached themselves. The melancholy plan to increase Portland's population from 300,000 to three million succeeded in disordering and unfocussing its growth: but it did little to give it the benefit of modern city planning practice; meanwhile, the apparent financial prospects of these port cities undermined the base of the sounder development that could well have been taking place in other parts of the region, on strictly modern lines.

His solution: build new towns in a landscape that literally took his breath away. Some 60 years later, downtown Portland is a national model, but downtown was being rebuilt in the depths of the recession of the 1980's because of initiatives put into motion 20 and 30 years before. Creating a great place, however you define it, and over whatever scale you are working at, is the legacy of a lifetime, not a matter of months, a single term of office, or the cutting of a single ribbon. Stewardship takes place over generations, not all at once.

6) You can't regulate Quality of Life into Existence. Planners have lots of tools for limiting damage. However, community quality of life is a collective achievement. The great parks of our region didn't result from exactions, but from bond measures and other collective measures. Modeling work accompanying the development of the Region 2040 Growth Concept found that even with the ideal arrangement of land uses and buildings with relation to the transportation system, transportation system goals would not be met without changes in trip making behavior.

That is, absent a culture of inhabitation to go along with the physical development of the landscape, plan objectives would not be realized and community values wouldn't be served. Achieving quality of life goals is a partnership between what is required and the choices made by individuals. 
Regulation alone is not sufficient. Putting choice into context remains a central challenge for planners.

7) Things Change - There is a difference between planning when times are good and planning when times are bad. When times are bad communities seek change. When times are good, communities seek to stabilize the status quo, and planners speaking of change might as well be speaking in tongues. In the mid-1980's, our region sought any kind of change it could. In the early 1990's as the pace of growth began to pick up, the communities became more critical of the change that was occurring and the change that they sought. Today, there are a significant number of people calling for either no growth or slower rates of change, and today unemployment is at historic lows.

Recently the City of Portland engaged in a district planning process in the southwestern part of the city. The Southwest Community Plan was met with sustained and passionate opposition, especially when it became clear that the purpose of the plan was to change zoning to accommodate even more growth. However, the southwest district reported the highest level of satisfaction with neighborhood conditions on a survey conducted at about the same time the planning effort encountered its peak opposition. In that case, neighbors weren't seeking change. When times are good, the challenge is to make the present work better, and planning strategies and objectives need to change. The only constant is the underlying values of the community.

8) Growth Management has Costs as well as Benefits - Planners have known for some time that sprawl is not free. Recent studies revisiting the "costs of sprawl" question in Oregon and elsewhere have reconfirmed that sprawl and its inefficiencies carry a cost. However, we've also learned that the alternatives to sprawl aren't free either. Every choice entails a cost, and growth management can make the nature of the challenge of creating equitable regions even more explicit.

Although numerous studies have been developed to determine the cost imposed by the urban growth boundary, none has been able to demonstrate that the urban growth boundary alone is the reason, even a significant reason, for rising housing costs in this region (Goodstein, OHCS, Florida).

Nonetheless, choosing an urban growth boundary both incurs a cost of some magnitude and, perhaps most important, implies that traditional methods for supplying affordable housing--devaluing central cities and older suburbs while minimizing land costs elsewhere--won't be available here. Our challenge, like that throughout the country, remains identifying ways to house the least affluent households in our region in locations close to services and jobs. Growth management doesn't relieve us of facing up to that challenge, just as sprawl doesn't relieve other regions of the same challenge.

9) An Urban Growth Boundary is not an Urban Growth Management Program The motivation for the Region 2040 planning program grew out of the realization in 1989 that we were experiencing all of the same "sprawl effects" of other metropolitan areas within the urban growth boundary in this 
metropolitan area. On the other hand, it has been demonstrated that the urban growth boundary has protected farm land, helped to sustain farm production, and established a clear difference in urban and rural resource land values. Further, a parcel map of the region reveals that the urban growth boundary has clearly separated urban densities from rural densities.

Although the urban growth boundary has had the intended effect of protecting farm land and farming, it has not prevented sprawl patterns of development within the urban area. That is, it is a very powerful and useful tool, but no silver bullet. A comprehensive growth management program can benefit from an urban growth boundary, but it also requires action and attention at other scales.

Neighborhoods, streets, town centers, mainstreets, regional centers, and greenspaces all need specific attention. Design matters at every scale. High quality public spaces, creating locations of choice within the metropolitan area, don't happen by accident. Urban growth boundaries force conscious choices about urban structure and urban/rural relationships. What happens within the boundaries requires other tools and initiatives.

10) Community Building, both locally and regionally, is an Ongoing Responsibility - At the turn of the century, Portland's booster message was simple. Portland just wanted to be big, the "Queen City" of the Pacific coast. Today, on the cusp of a new century, a quest for bigness is not a sufficient booster message. Attention has turned to being better, and improving the quality of a place automatically brings into focus questions of cost, collective responsibility, and political will. Our experience is that regional planning is fundamentally a community building task. Furthermore, if people aren't empowered locally, if they don't feel effective in arenas close to home, they won't be able to relate to a regional plan.

Consequently, an ongoing effort needs to be made to build both strong local communities and collective recognition of a shared metropolitan future. One without the other won't ring true and won't go far. Ultimately competitiveness at a metropolitan scale is not just about doing things well that other places can do, but doing things well unique to your own metropolitan area. In Portland we live in a landscape with oceans, mountains, deserts, wilderness, and incredible fresh food all within the same day's drive. We can drink the water from the tap and still see the mountains on the horizon. If Portland can continue to make and remake itself as the best place it can be, then the strength of our collective ideas and action will continue to be of interest to the world. No one will visit us to see a better version of some other place.

\section{Conclusions...}

The fact that we can draw these lessons from our experience should not suggest that we've continued to live by and remember them in every situation. Portland, like every place, needs to continue to focus and refocus on our shared values, 
particularly as the community changes. Asking and re-asking questions about basic values is what keeps plans and communities alive. We are still struggling to understand both the impact of our choices and our responsibilities for addressing them. In some areas, like planning for the future accommodation of needs for air transportation services or linking land use plans across a state line, we are just now creating a common context for the hard work to come.

Growth management is primarily a game of rates: forecasting rates of growth, assigning growth to locations, attempting to match rates of growth with the provision of infrastructure and services. Growth management has been portrayed in the past as a means for accommodating new growth as if it never happened. That is, the impact of new growth would presumably be minimized as its requirements were recognized and addressed in advance through growth management efforts.

Though it is important to know how big things might get and by when, and to ensure that communities can grow into themselves gracefully when the time comes, we've learned that you can't manage away the effects of growth. More people means more activity, more competition for fishing holes, and more folks in the check-out line no matter how good the growth management effort has been. Growth, like decline, results in change.

There are several questions worth exploring through planning, but these are not typical growth management questions. First, how can new growth assist communities with maturing? Most often, discussions of growth are about adding something new. Rather than focussing on newness, how can growth assist places with becoming more mature, with better making the fit between local aspiration, environmental quality, and sustainability? Second, no matter how many people show up, and no matter when they get there, what ought to still be true about the community?

We've learned that planning cannot prevent change. Change is a constant. However, planning can advance values. What are the qualities that ought to still be evident, still be true about the place in the future? Planning can make great strides in that direction as evidenced in Portland's downtown, its neighborhoods, and in the vitality of the working landscape surrounding the rapidly expanding "silicon forest."

Ultimately, as the "Eden at the end of the Oregon Trail", we are still trying to figure out just what a city in Eden looks like. Most of our planning to this point has been prompted by a desire to sustain Oregon's traditional economy, and its reliance on high quality farm and forest land. Many if not most of the innovations that we're known for are innovations of preservation. However, city building is a creative act, and an uncharted challenge in this country at a metropolitan scale. There is no blueprint for an urban vision in Eden. Our struggle in the years ahead will be creating for ourselves a vision of urbanity in this western place. Make no mistake, what we've done and what we're doing is all a work in progress. May it ever be so. 
Ethan Seltzer is currently the Director of the Institute of Portland Metropolitan Studies at Portland State University. The Institute is a new initiative of the University, created to better link faculty and students to the issues confronting metropolitan area communities. Prior to coming to the University, he was the Land Use Supervisor for Metro, and principally responsible for developing Metro's "Regional Urban Growth Goals and Objectives" He has lectured in Canadian and US metropolitan regions on the regional planning activities in the Portland metropolitan area. His research interests and publications range from the involvement of children in planning to the history of the urban growth boundary concept in Oregon planning. He received his Ph.D. In City and Regional Planning from the University of Pennsylvania in 1983. For more information, he can be contacted via e-mail at the following address: ethan@upa.pdx.edu 